CT\&F - Ciencia, Tecnología y Futuro - Vol. 4 Num. 3 Jun. 2011

ctył@ecopetrol.com.co

\title{
FLUID MIGRATION HISTORY FROM ANALYSIS OF FILLING FRACTURES IN A CARBONATE FORMATION (LOWER CRETACEOUS, MIDDLE MAGDALENA VALLEY BASIN, COLOMBIA)
}

\author{
Jairo Conde-Gómez ${ }^{1}$, Luis-Carlos Mantilla-Figueroa ${ }^{1}$, Julián-Francisco Naranjo-Vesga ${ }^{2 *}$ and \\ Nelson Sánchez-Rueda ${ }^{2}$ \\ 1 Universidad Industrial de Santander, Bucaramanga, Santander, Colombia \\ ${ }^{2}$ Ecopetrol S.A. - Instituto Colombiano del Petróleo (ICP), A.A. 4185 Bucaramanga, Santander, Colombia
}

e-mail: julian.naranjo@ecopetrol.com.co

ABST

(Received Oct. 15, 2010; Accepted Jun. 01, 2011)

Petrographic and SEM data indicate that the veins are fracture filling structures, with three types of textures: 1) Granular aggregates of calcite $(G A)$; 2) Elongated granular aggregates of calcite (EGA); and 3) Fibrous aggregates of calcite and dolomite (FA). The textural relationship suggests that GA must have been formed in an environment of widespread extension of the basin, while EGA and FA must have been formed in a compressive environment. The geochemical analyses of REE carried out in the dominant fill of the veins (GA) indicate that these fillings must have been formed in a closed system (intraformational fluid movement) for the drilling well Alfa-1, while in the drilling wells Alfa-2 and Alfa 3, these fills (GA) must have been formed in a characteristic environment of open system (transformational fluid movement). Two pulses of hydrocarbon migration were identified through the study of fluid inclusions: In the first event, light hydrocarbons and aqueous fluids $\left(\mathrm{H}_{2} \mathrm{O}-\mathrm{NaCl}-\mathrm{CaCl}_{2}\right)$ migrated trough the primary porosity and fractures at temperatures between $60^{\circ} \mathrm{C}-90^{\circ} \mathrm{C}$. In the second event, light hydrocarbons associated with aqueous fluids $\left(\mathrm{H}_{2} \mathrm{O}-\mathrm{NaCl}-\mathrm{CaCl}_{2}\right)$ migrated through fractures at temperatures between $70^{\circ} \mathrm{C}$ $120^{\circ} \mathrm{C}$. Data obtained in this investigation will strengthen the knowledge about the hydrocarbon migration history and entrapment in the Middle Magdalena Valley basin (VMM) particularly in the lower Cretaceous age reservoirs.

Keywords: Middle Magdalena Valley basin, Rosablanca Formation, Petrography, Rare earth geochemistry, Fluid inclusions.

Citation: Conde, J., Mantilla, L.C., Naranjo, J. F. \& Sánchez, N. (201 1). Fluid migration history from analysis of filling fractures in a carbonate formation. (Lower cretaceous, middle Magdalena Valley basin, Colombia). CT\&F - Ciencia, Tecnología y Futuro, 4(3), 21-36.

*To whom correspondence may be addressed 


\section{RESUMEN}

$\mathrm{E}$ I estudio integral realizado mediante Petrografía Convencional, SEM, geoquímica de Tierras Raras (REE) y análisis de Inclusiones Fluidas (IF) en el relleno de fracturas de la Formación Rosablanca (Cuenca del Valle Medio del Magdalena), permite relacionar eventos de apertura y relleno de las fracturas con procesos de migración de hidrocarburos. Los datos petrográficos y de SEM indican que las venas son estructuras de relleno de fracturas con tres tipos de texturas: 1) Agregados granulares de calcita (AG); 2) Agregados granulares elongados de calcita (AGE); y 3) Agregados fibrosos de calcita y dolomita (AF). La relación textural sugiere que los AG debieron formarse en un ambiente de extensión generalizada de la cuenca, mientras que los AGE y AF debieron haberse formado en un ambiente compresivo. Los análisis geoquímicos de REE efectuados en los rellenos dominantes de las venas (AG) en el pozo Alfa-1, indican que estos rellenos debieron formarse en un sistema cerrado (circulación intraformacional de fluidos), mientras que en los pozos Alfa-2 y Alfa-3 debieron formarse en un ambiente característico de sistema abierto (flujo transformacional de fluidos). Dos pulsos de migración de hidrocarburos fueron identificados mediante el estudio de inclusiones fluidas: En el primer evento migraron a través de la porosidad primaria y fracturas hidrocarburos livianos y fluidos acuosos $\left(\mathrm{H}_{2} \mathrm{O}-\mathrm{NaCl}-\mathrm{CaCl}_{2}\right)$ con temperaturas mínimas entre $60^{\circ} \mathrm{C}-90^{\circ} \mathrm{C}$. En el segundo evento migraron a través de las fracturas hidrocarburos livianos asociados con fluidos acuosos $\left(\mathrm{H}_{2} \mathrm{O}-\mathrm{NaCl}-\mathrm{CaCl}_{2}\right)$ a temperaturas entre $70^{\circ} \mathrm{C}-120^{\circ} \mathrm{C}$. Los datos obtenidos en esta investigación fortalecerán el conocimiento sobre la historia de migración y entrampamiento de hidrocarburos en la Cuenca del Valle Medio del Magdalena (VMM) particularmente en los reservorios de edad Cretácico inferior.

Palabras claves: Cuenca Valle Medio del Magdalena, Formación Rosablanca, Petrografía, Geoquímica de tierras raras, Inclusiones fluidas.

\section{RESUMO}

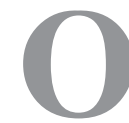

estudo integral realizado mediante Petrografia Convencional, SEM, geoquímica de Terras Raras (REE) e análise de Inclusões Fluidas (IF) no preenchimento de fraturas da Formação "Rosablanca"

(Bacia do Vale Médio do Magdalena), permite relacionar eventos de abertura e preenchimento das fraturas com processos de migração de hidrocarbonetos. Os dados petrográficos e de SEM indicam que as veias são estruturas de preenchimento de fraturas com três tipos de texturas: 1) Aglomerados granulares de calcita (AG); 2) Aglomerados granulares alongados de calcita (AGE); e 3) Aglomerados fibrosos de calcita e dolomita (AF). A relação textural sugere que os AG provavelmente foram formados em um ambiente de extensão generalizada da bacia, enquanto que os AGE e os AF devem ter sido formados em um ambiente compressivo. As análises geoquímicas de REE realizadas nos preenchimentos dominantes das veias (AG) no poço Alfa- 1 indicam que estes preenchimentos devem ter sido formados em um sistema fechado (circulação intraformacional de fluidos), enquanto que nos poços Alfa-2 e Alfa-3 provavelmente foram formados em um ambiente característico de sistema aberto (fluxo transformacional de fluidos). Dois pulsos de migração de hidrocarbonetos foram identificados mediante o estudo de inclusões fluidas: No primeiro evento migraram através da porosidade primária e fraturas de hidrocarbonetos leves e fluidos aquosos $\left(\mathrm{H}_{2} \mathrm{O}-\mathrm{NaCl}-\mathrm{CaCl}_{2}\right) \mathrm{com}$ temperaturas mínimas entre $60^{\circ} \mathrm{C}-90^{\circ} \mathrm{C}$. No segundo evento migraram através das fraturas de hidrocarbonetos leves associados com fluidos aquosos $\left(\mathrm{H}_{2} \mathrm{O}-\mathrm{NaCl}-\mathrm{CaCl}_{2}\right)$ a temperaturas entre $70^{\circ} \mathrm{C}-120^{\circ} \mathrm{C}$. Os dados obtidos nesta pesquisa fortalecerão o conhecimento sobre a história de migração e aprisionamento de hidrocarbonetos na Bacia do Vale Médio do Magdalena (VMM), particularmente nos reservatórios de idade Cretácico inferior.

Palavras chaves: Bacia Vale Médio do Magdalena, Formação Rosablanca, Petrografia, Geoquímica de terras raras, Inclusões fluidas. 


\section{INTRODUCTION}

In sedimentary basins, fracture systems can become important migration routes for hydrocarbons, watery fluids or a mixture of both. The physicochemical conditions of these fluids can be studied through the analysis of the minerals that fill the veins. Likewise, the textures of the minerals may reflect multiple events of opening and filling, and deformational processes that occurred during the precipitation of minerals (Misik, 1971; Fisher \& Brantley, 1992; Dunne \& Hancock, 1994; Wilson, 1994; Cox, 2005). The integrated studies of inorganic geochemistry, fluid inclusions and petrography have become integral tools for the analysis in these systems during recent years, because they provide information about mineral paragenesis, temporal sequence of events of opening and filling of fractures, the source of the fluids, physicochemical conditions (such as chemical system, salinity, temperature, pressure and depth of the fluids that circulate through the fractures) and the determination of migration events or load of hydrocarbons (Suchy et al., 2000; Hood, Campbell \& Kamp, 2003; Kontak, Kyser, Gize \& Marshall, 2006).

In this work conventional petrology studies, scanning electron microscopy (SEM), fluid inclusions and geochemistry of rare earth elements (REE) were performed in mineral filling of fractures found in witnesses of the Rosablanca formation, extracted from boreholes Alfa-1, Alpha-2 and Alpha-3 (Figure 1), located in the Middle Magdalena Valley Basin (VMM). The main objectives of this study are:

a. To determine the mineralogy and the texture of the filling minerals of the fractures.

b. To establish the history of opening and filling of fractures, as well as loading events and migration routes of hydrocarbons.

c. To determine the physicochemical characteristics of the fluids that circulated through the fractures.

d. To establish the source of these fluids.

e. To relate the opening and filling events with the regional tectonic regime.

The results obtained from this investigation are a contribution to the knowledge of the thermal history of the Rosablanca Formation and to the physicochemical nature of the fluids (hydrocarbon and aqueous fluids) that circulated through this unit at various times of its geologic history.

\section{THEORICAL FRAMEWORK}

\section{Geological Context}

The exploratory wells Alpha-1, Alpha- 2 and Alpha-3 (the names of the wells have been changed for reasons of confidentiality) are located in the Middle Magdalena Valley basin (VMM) (Figure 1). At the structural level, this basin is bordered to the North by the fault system of the Holy Spirit, to the North-East by the fault system Bucaramanga-Santa Marta, to the South-East by the fault system of Bituima, to the South by the folding belt of Girardot, and to the west by the base of the Central mountain range (Barrero, Pardo, Vargas \& Martínez, 2007) (Figure1). The sedimentary sequence of the VMM (Figure 2) is made up of siliciclastic and calcareous rocks of the Jurassic period (Girón Group), the Cretaceous (formations Los Santos, Cumbre, Rosablanca, Paja, Tablazo, Simití, La Luna and Umir), Paleogene (formations Lizama, La Paz, Esmeraldas, Mugrosa and Colorado) and Neogene (Real Grup and Mesa Formation) which were deposited at continental, fluvial, transitional, and shallow marine platform environments (Morales et al., 1958; Cooper et al., 1995; Villamil, 1999; Gómez, Jordan, Allmendinger, Hegarty \& Kelley, 2005).

The sedimentation of the Jurassic and Cretaceous units occurred in a regional tectonic distensive-type scheme, in which a syn-rift and post-rift mega sequence was formed with the development of back-arc type basins such as Tablazo-Magdalena (Cooper et al.,1995), which was filled with transitional continental and marine sediments (Fabre, 1983). At the end of the Cretaceous the accretion of the western mountain range originated a change in the tectonic regime predominant until that moment, which was reflected in the change of a marine sedimentation to one of continental and transitional type (Cooper et al., 1995). The sedimentation of the Paleogene and Neogene units occurred in a comprehensive-type tectonic environment in which the VMM behaved as a basin 


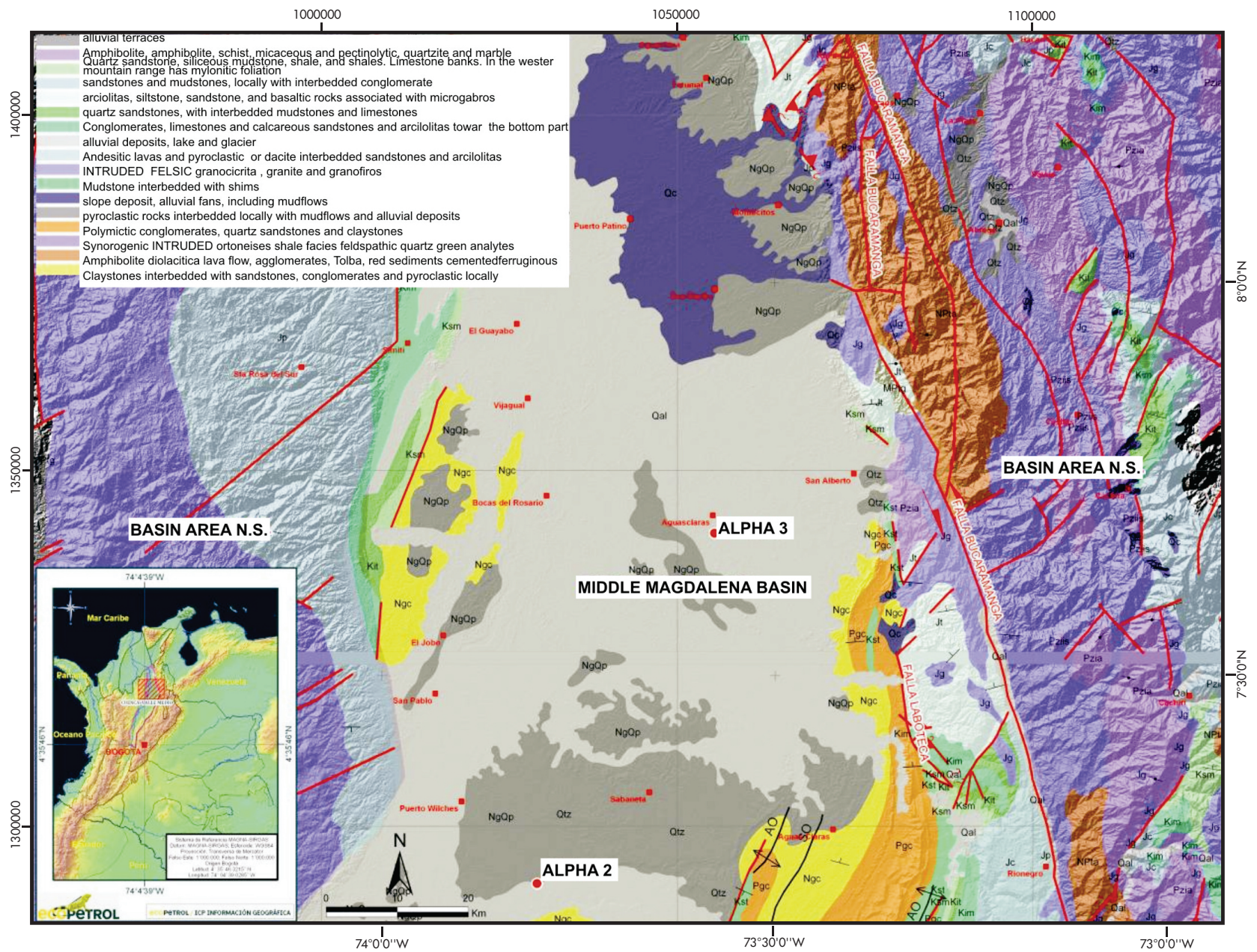

Figure 1. Location of Wells Alpha-2 and Alpha 3 in Middle Magdalena Valley (VMM). The location of well Alpha-1 is omitted for reasons of confidentiality of the information. Modified image of ECOPETROL S.A. - ICP internal maps

of foreland type until the lower Eocene (Villamil, 1999), receiving sediments from of the Central mountain range. Subsequently, the pre-Andean Orogeny (Villamil, 1999; Gómez et al., 2005) affected the lower pre-Eocene sequence creating folds and thrusting in the VMM, which were truncated and later coated with clastic rocks of the Superior Eocene (Cooper et al., 1995). From that moment the VMM basin has behaved as an intermountain basin that has received sediments from the Central and Western mountain ranges, which experienced their biggest deformational phase during the Miocene (Cooper et al., 1995; Villamil, 1999; Sarmiento, 2001).

The Rosablanca Formation, the present study's object according data reported by Julivert (1963), is of Hauterivian -Barremian GEA, is transitionally underlain by levels of sandstone with crossed stratification that belongs to the Tambor formation, and clearly overlain by the lutites of the Paja Formation (Morales et al., 1958). According to Leon (2002) this unit was deposited only in the center and south of the basin of the VMM, in an environment of shallow marine platform, in environments of tidal plains of subtidal intertidal and supratidal types (Alfonso,1985). Lithologically, it is a calcareous unit represented by facies of mudstones, wackestone and packstone of bioclasts (Rolon \& Numpaque, 1997). The early studies on fracture filling in the Rosablanca Formation are represented by two works: the first one by Mantilla, Tassinari \& Mancini, (2006) who performed analysis of carbon, oxygen, and strontium isotopes and of rare earth elements (REE) in carbonate veins and rock box, whose results indicated an isotopic difference between the carbonate veins and enclosing rock, which suggests an intervention of aloctone waters that circulated through the fracture system; furthermore, they 
suggest that the REE present in the carbonates of the veins came from a different source to the enclosing rock. The other work, by Naranjo, Duque y Moreno, (2009), carried out stu-dies of fluid inclusions, petrography and cathode lumi-nescence in fractures filled with carbonates, where they found evidence of diagenetic processes previous to the formation of the fractures that modified their quality as reservoir rock, as well as at least two load or migration events of hydrocarbons, which used microfractures and the intergranular and intercrystalline space as leak canals.

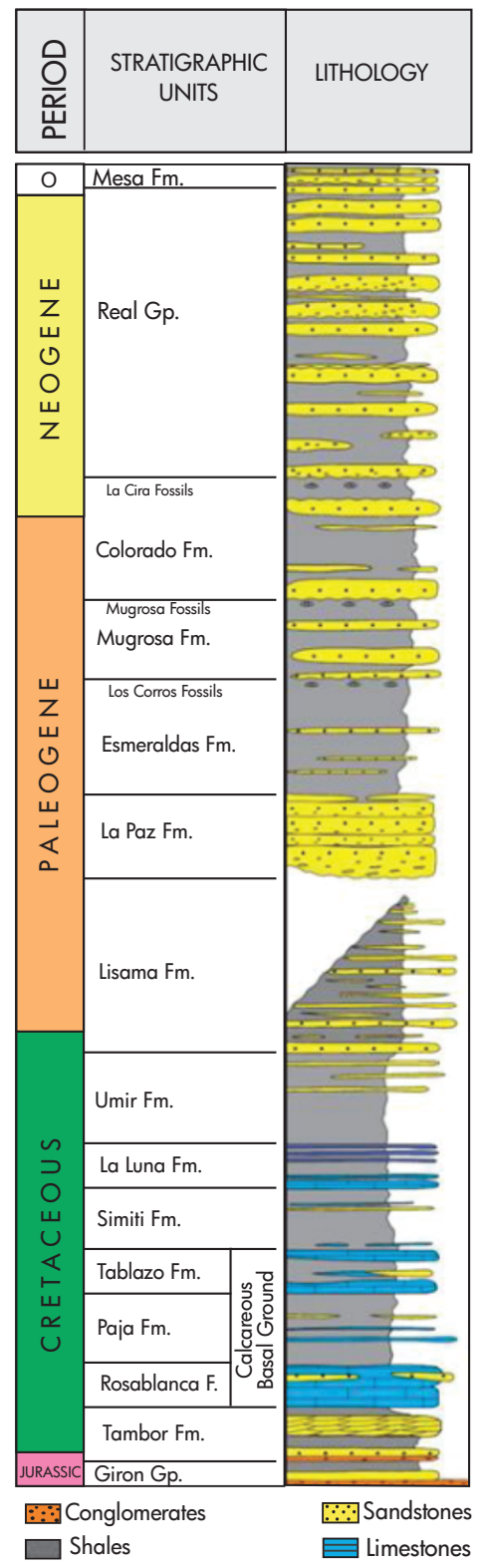

Figure 2. Generalized stratigraphic column of Middle Magdalena Valley, modified of Barrero et al., (2007)

\section{EXPERIMENTAL DEVELOPMENT}

\section{Methodology}

For the development of this research 13 samples of associated veins were analyzed with their respective enclosing rock which stratrigraphically belongs to the Rosablanca Formation. (Figure 3)

The elaboration of the thin sheets (for petrographic purposes) and double-polished (for the study of fluid inclusions) was carried out in the Geologic Sample Processing Laboratory of the ICP. The petrographic analyses for the identification of the different textural associations present in the filling materials and the minerals that compose them, were done in the Optical Microscopy Laboratory of the School of Geology of the Universidad Industrial de Santander (UIS), using a Nikon Eclipse E-200 transmitted light microscope. The SEM explorations carried out mainly to support the textural study of the filling materials of the veins and to identify the mineralogical composition of the fracture filling minerals, were carried out in the electron microscopy laboratory of the WWICP with the help of a Leo 1450VP electron microscope equipped with an OXFORD INCA disperse energy $\mathrm{X}$ ray system, with which it was possible to observe images through secondary and backscattered electrons (BSE - backscattering).

The microthermometric analyses in FI were done in the Geology Laboratory of the UIS (GuatiguaráPiedecuesta Headquarters), using a Carl Zeiss Axiolab transmitted light microscope, coupled to a Moticam 5000 cooled digital camera and to a Linkam THMS600 slide. A Nikon microscope coupled to a source of ultraviolet light of $365 \mathrm{~nm}$ of wavelength, available in the ICP's Petrography Laboratory, was equally used for corroborating the existence of FI with hydrocarbons.

The REE analyses were done in the ICP's Geochemistry laboratories, using an inductively coupled plasma mass spectrometer (ICP-MS), type ELAN600 $\mathrm{PE}$. These analyses were done mainly for quantitatively determining compositional differences between the rock box and the filling of fractures associable with the intra- and extra-formational movement of fluids. 


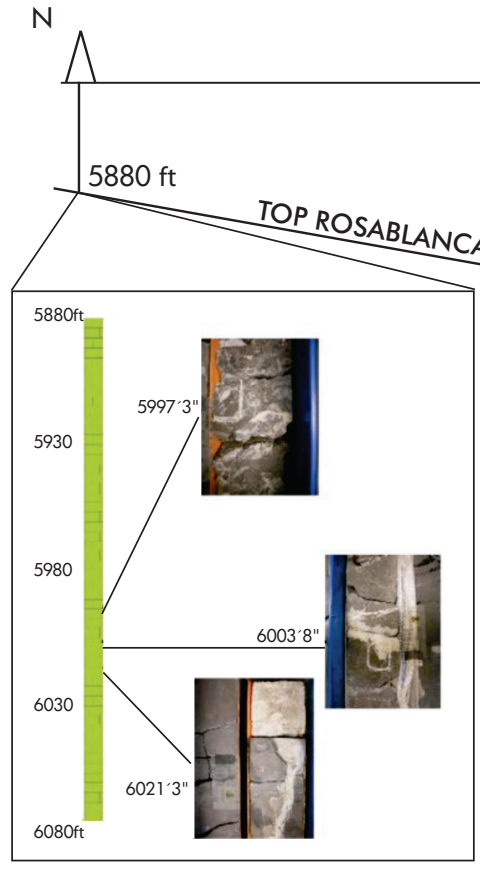

WELL ALPHA 1

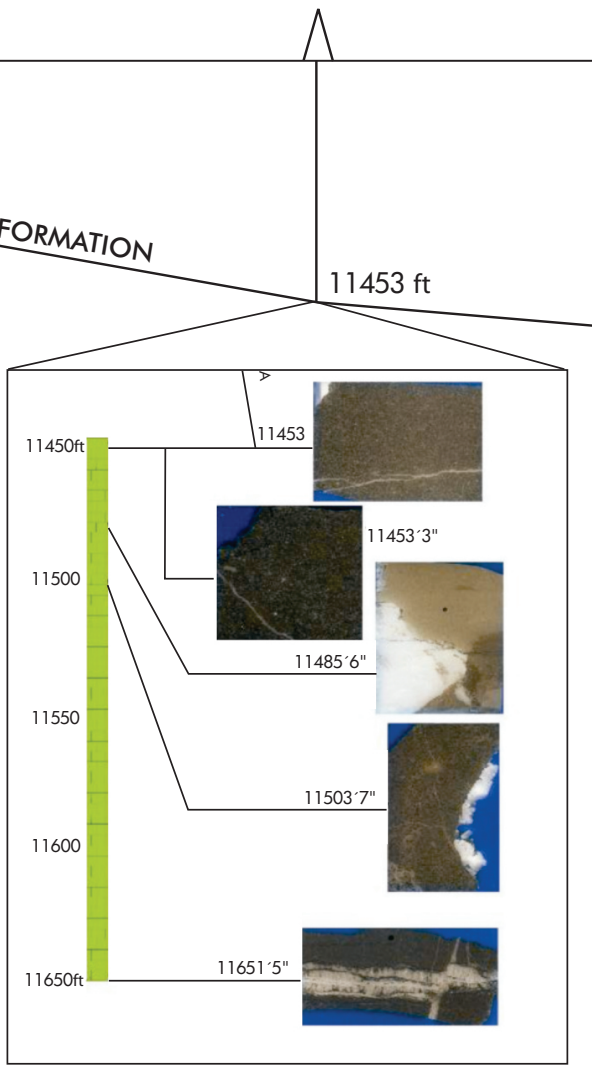

WELL ALPHA 3
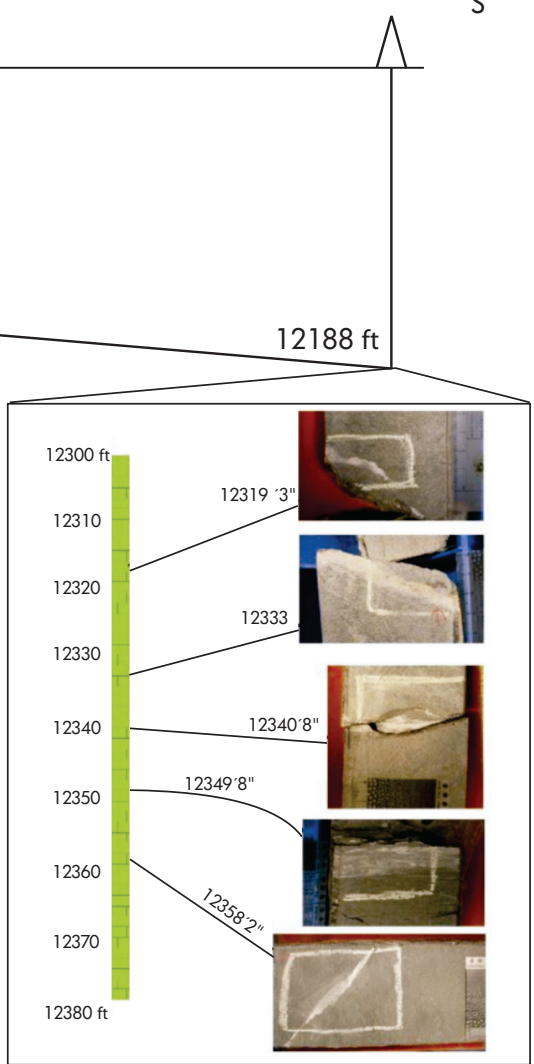

WELL ALPHA 2

Figure 3. Regional N-S scheme which shows the top of the Rosablanca formation for the wells Alpha 1, Alpha 2 and Alpha 3, as well as the samples of veins associated with box rock of this unit chosen for the petrographic analyses, SEM, FI and Geochemistry of Rare Earth Elements (REE)

\section{RESULTS}

\section{Petrography and SEM}

In the mineralogical aspect, the fractures found in the core of the Rosablanca Formation of the exploratory wells Alpha-1, Alpha-2 and Alpha-3 are filled predominantly with carbonates that are texturally associated to granular aggregates (GA), granular aggregates of elongated crystals (GEA) and fibrous aggregates (FA) (Figures 4 and 5).

\section{Granular aggregates (GA)}

They are mainly formed by calcite and punctually barite, celestite, pyrite and quartz; as was clarified through SEM explorations. The calcite that forms this association is presented subhedrally and anhedrally, with sizes between 0,1 and $2 \mathrm{~mm}$. The bigger crystals of this textural association have inclusions of the enclosing rock.

\section{Granular Elongated Aggregates (GEA)}

They are mainly formed by calcite with euhedral forms of tabular habit and sizes ranging between $0,2 \mathrm{~mm}$ and $1 \mathrm{~mm}$. The crystals that compose this textural association are oriented perpendicularly in relation to the wall of the enclosing rock and parallel to one another.

\section{Fibrous Aggregates (FA)}

They are composed by dolomite in the exploratory well Alpha-3 according the punctual SEM analyses; and by calcite in the exploratory wells Alfa- 1 and 2 . The crystals that make up this fami-ly present broadleaf habit and size between 0,1 to $1,5 \mathrm{~mm}$. They are oriented perpendicularly to the wall of the enclosing rock. 

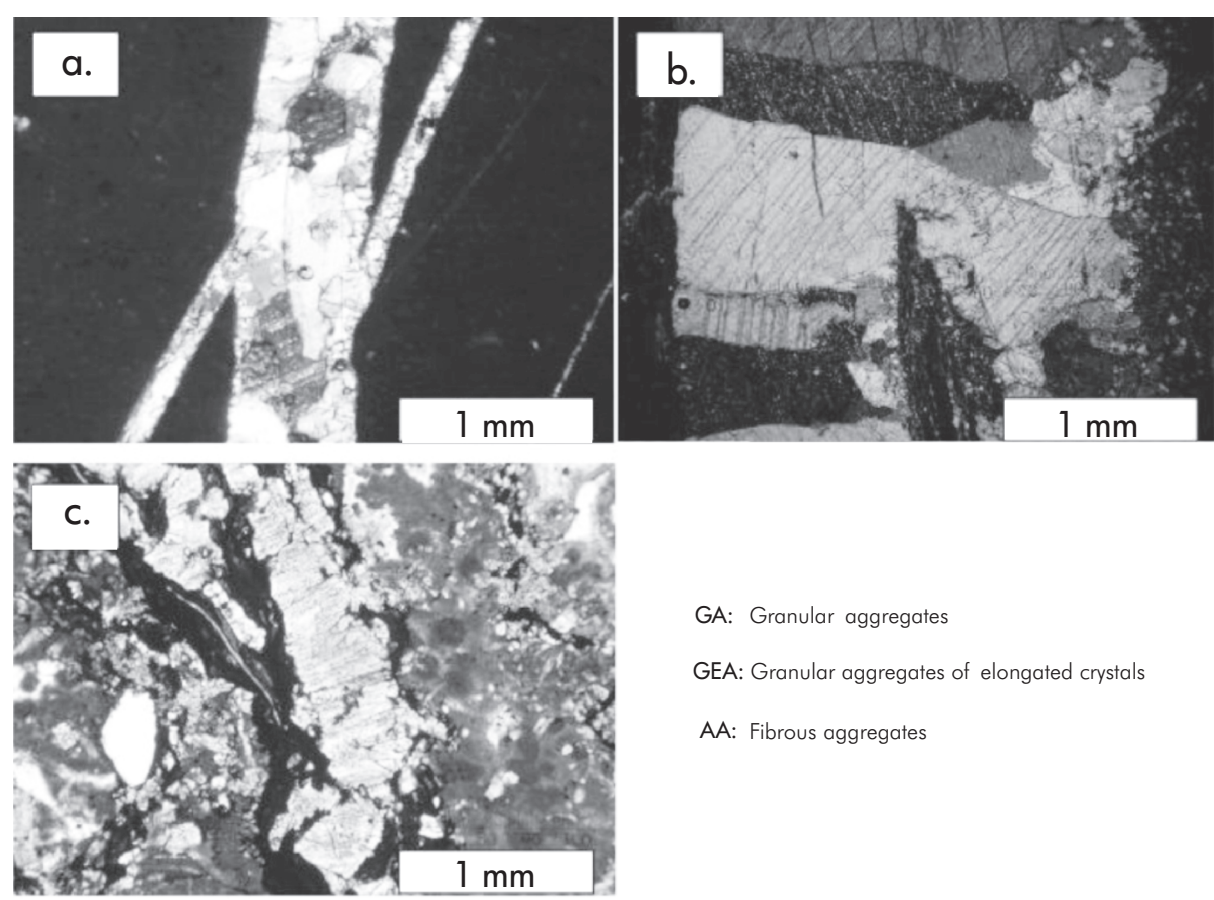

GA: Granular aggregates

GEA: Granular aggregates of elongated crystals

AA: Fibrous aggregates

Figure 4. Types of textural filling in the veins of the Rosablanca Formation; a) Granular aggregates (GA) in fractures of the well Alpha-1, b) Granular Elongated Aggregates (GEA) in fractures of the well Alpha-2; and c) Fibrous Aggregates (FA) in fractures of the well Alpha 3
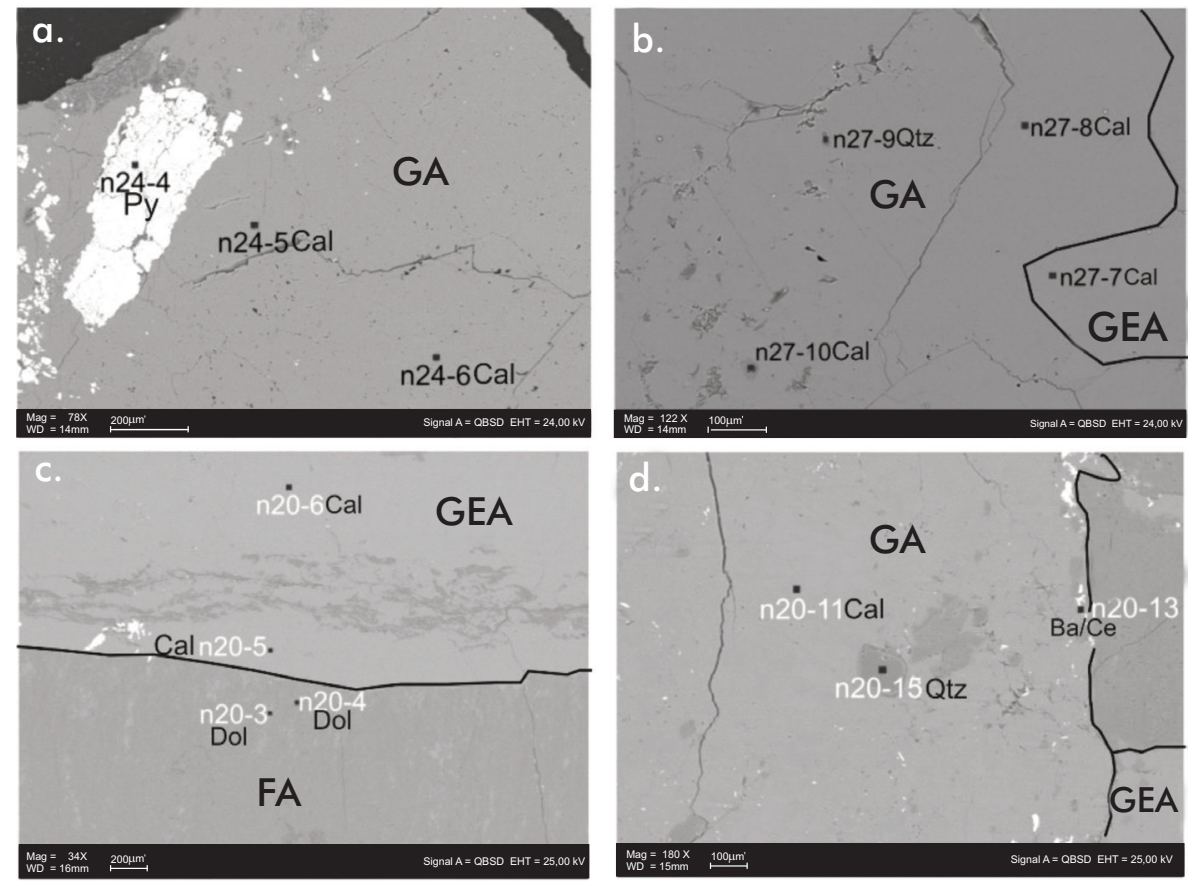

Figure 5. Semiquantitative compositional SEM analysis done for specifying the mineral phases present. $(\mathrm{Cal}=$ Calcite, $\mathrm{Dol}=$ Dolomite, $\mathrm{Qtz}=\mathrm{Quartz}, \mathrm{Ba} / \mathrm{Ce}=$ Baryte$/$ Celestite, Py= Pyrite). Granular Aggregates (GA), Granular Elongated Aggregates (GEA) and Fibrous Aggregates (FA) 


\section{Geochemistry of Rare Earth Elemenets (REE)}

The geochemical analysis of the rare earth elements (REE) was done in the enclosing rock and in the carbonates belonging to the granular aggregates (GA). In the Granular Elongated Aggregates (GEA) and Fibrous Aggregates (FA) it was not possible to do these analyses because they are present in a low proportion and their extraction was not possible.

The concentrations in parts per million of REE in the carbonates of granular aggregates and enclosing rocks are illustrated in Table 1. These data lead to the following interpretations: a) The amount of REE is bigger in the box rock, compared to the percentage of carbonates in the granular aggregates, except for the exploratory well Alpha-2, where the opposite trend is observed. b) In the enclosing rock as well as in the granular aggregates, the light rare earth elements are those with a higher concentration while the heavy rare earth elements are those with a lower concentration. c) As for the enclosing rock, the limestone of the well Alpha-3 presents the highest concentrations of REE while that of the well Alpha-2 presents the lowest concentration of REE. d) As for the granular aggregates that fill the fractures, the well Alpha-2 has the highest concentrations of REE while the well Alpha-1 presents the lowest amount.

In order to establish the anomalies of cerium and europium graphically and in numeric data, the values reported by Taylor and McLennan (1985) for the Chondrite $C 1$ were taken as referents. The standard data were obtained through the formula sample/chondrite $\mathrm{C} 1$ for each element and the formulas $E u N / \sqrt{ }\left(S m N^{*} G d N\right)$ and $C e N / \sqrt{ }\left(\operatorname{LaN}{ }^{*} \operatorname{Pr} N\right)$ were used following Rollinson's

Table1. Concentration of REE in ppm, measured in samples of granular aggregates that fill fractures and in samples of rock box of the Rosablanca Formation in wells Alpha-1, Alpha-2 and Alpha-3

\begin{tabular}{|c|c|c|c|c|c|c|}
\hline \multirow{3}{*}{ REE(PPM) } & \multicolumn{6}{|c|}{ ROSA BLANCA FORMATION } \\
\hline & \multicolumn{2}{|c|}{ WELL ALPHA 1} & \multicolumn{2}{|c|}{ WELL ALPHA 2} & \multicolumn{2}{|c|}{ WELL ALPHA 3} \\
\hline & LIMESTONE & $\begin{array}{c}\text { FILLING OF } \\
\text { FRACTURE } \\
\text { (GRANULAR } \\
\text { AGGREGATE) }\end{array}$ & LIMESTONE & $\begin{array}{c}\text { FILLING OF } \\
\text { FRACTURE } \\
\text { (GRANULAR } \\
\text { AGGREGATE) }\end{array}$ & LIMESTONE & $\begin{array}{c}\text { FILLING OF } \\
\text { FRACTURE } \\
\text { (GRANULAR } \\
\text { AGGREGATE) }\end{array}$ \\
\hline La & 7,7790 & 0,7310 & 5,6180 & 2,6110 & 29,2700 & 2,2740 \\
\hline $\mathrm{Ce}$ & 13,2400 & 0,8860 & 11,7500 & 10,3100 & 52,1600 & 6,8930 \\
\hline $\operatorname{Pr}$ & 1,5620 & 0,1130 & 1,4090 & 2,2980 & 6,3200 & 1,0140 \\
\hline $\mathrm{Nd}$ & 5,9020 & 0,4340 & 5,4640 & 16,0100 & 22,4900 & 4,5430 \\
\hline Sm & 1,0790 & 0,0870 & 1,0660 & 6,0970 & 4,2700 & 1,0090 \\
\hline Eu & 0,2560 & $<0,023$ & 0,2910 & 10,4900 & 1,0000 & 0,3180 \\
\hline Gd & 1,3180 & 0,1080 & 1,2260 & 7,0650 & 4,6920 & 1,0150 \\
\hline $\mathrm{Tb}$ & 0,1810 & $<0,037$ & 0,1580 & 0,8360 & 0,6200 & 0,1230 \\
\hline Dv & 0,9940 & 0,0700 & 0,8740 & 3,9660 & 3,2860 & 0,5600 \\
\hline Ho & 0,2130 & $<0,034$ & 0,1590 & 0,6460 & 0,6560 & 0,1020 \\
\hline Er & 0,6170 & 0,0370 & 0,4180 & 1,3410 & 1,9280 & 0,2550 \\
\hline$T m$ & 0,0890 & $<0,019$ & 0,0570 & 0,1270 & 0,2790 & 0,0270 \\
\hline $\mathrm{Yb}$ & 0,5720 & $<0,043$ & 0,3650 & 0,6070 & 1,8670 & 0,1450 \\
\hline Y & 7,2550 & 0,4980 & 3,7400 & 3,13600 & 16,1200 & 3,5840 \\
\hline
\end{tabular}


proposal (1996). The results of these calculations are shown in Table 2 and in Figure 6 . The values $>1$ represent positive anomalies while the values $<1$ represent negative anomalies. In this sense the values of the anomalies in cerium in the samples of enclosing rocks indicate that all anomalies are negative. It is more noticeable (more negative) in the samples of the well Alpha-1 [CeN/V $\left.\left(\operatorname{LaN}^{*} \operatorname{Pr} N\right)=0,890\right]$ and Alpha-3 $[C e N / \sqrt{ }(\operatorname{LaN} * \operatorname{Pr} N)=0,899]$ and slightly smaller in the well Alpha-2 [CeN/ $\sqrt{ }\left(L a N^{*} \operatorname{PrN}\right)=$ 0,979]. The same trend is observed in the anomaly of europium for the enclosing rock, in which this anomaly is also negative, and it continues being more noticeable in the samples of limestone of

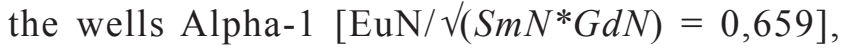

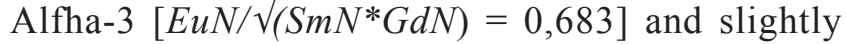
lower in the well Alpha-2 [EuN $\left./ \sqrt{ }\left(S m N^{*} G d N\right)=0,778\right]$.

The values of the anomalies in cerium in the carbonates of the fracture-filling granular aggregates indicate that the anomalies are negative for the Wells Alpha-1 [CeN/ $\sqrt{ }(\operatorname{LaN} * \operatorname{Pr} N)=0,722]$ and Alpha-2 $[C e N / \sqrt{ }(\operatorname{LaN} * \operatorname{Pr} N)=0,986]$; but they turn out to be posi-

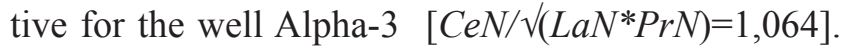
As for the anomaly of europium in carbonates of granular aggregates, it is observed that it is negative in the samples of the wells Alpha-1 $\left[E u N / \sqrt{ }\left(S m N^{*} G d N\right)\right.$ $=0,725]$ and Alpha-3 [EuN/ $\left.\sqrt{ }\left(S m N^{*} G d N\right)=0,960\right]$, but positive and very noticeable in the well Alpha-2 $\left[E u N / \sqrt{ }\left(S m N^{*} G d N\right)=4,884\right]$.

Table 2. Standard values of the REE concentrations regarding the chondrite $\mathrm{Cl}$, in samples of granular filling and rock box of the Rosablanca Formation in the wells Alpha-1, Alpha-2 and Alpha-3

\begin{tabular}{|c|c|c|c|c|c|c|}
\hline \multirow[b]{2}{*}{ REE(PPM) } & \multicolumn{2}{|c|}{ WELL ALPHA 1} & \multicolumn{2}{|c|}{ WELL ALPHA 2} & \multicolumn{2}{|c|}{ WELL ALPHA 3} \\
\hline & LIMESTONE & $\begin{array}{c}\text { FILLING OF } \\
\text { FRACTURE } \\
\text { (GRANULAR } \\
\text { AGGREGATE) }\end{array}$ & LIMESTONE & $\begin{array}{c}\text { FILLING OF } \\
\text { FRACTURE } \\
\text { (GRANULAR } \\
\text { AGGREGATE) }\end{array}$ & LIMESTONE & $\begin{array}{c}\text { FILLING OF } \\
\text { FRACTURE } \\
\text { (GRANULAR } \\
\text { AGGREGATE) }\end{array}$ \\
\hline La & 21,196 & 1,992 & 15,308 & 7,114 & 79,755 & 6,196 \\
\hline $\mathrm{Ce}$ & 13,835 & 0,926 & 12,278 & 10,773 & 54,504 & 7,203 \\
\hline $\operatorname{Pr}$ & 11,401 & 0,825 & 10,285 & 16,774 & 46,131 & 7,401 \\
\hline $\mathrm{Nd}$ & 8,301 & 0,610 & 7,685 & 22,518 & 31,632 & 6,390 \\
\hline Sm & 4,671 & 0,377 & 4,615 & 26,394 & 18,485 & 4,368 \\
\hline Eu & 2,943 & 0,264 & 3,345 & 120,575 & 11,494 & 3,655 \\
\hline Gd & 4,307 & 0,353 & 4,007 & 23,088 & 15,333 & 3,317 \\
\hline $\mathrm{Tb}$ & 3,121 & 0,638 & 2,724 & $, 14,414$ & 10,690 & 2,121 \\
\hline Dv & 2,609 & 0,184 & 2,294 & 10,409 & 8,625 & 1,470 \\
\hline Ho & 2,503 & 0,400 & 1,868 & 7,591 & 7,709 & 1,199 \\
\hline Er & 2,478 & 0,149 & 1,679 & 5,386 & 7,743 & 1,024 \\
\hline$T m$ & 2,500 & 0,534 & 1,601 & 3,567 & 7,837 & 0,758 \\
\hline$Y b$ & 2,306 & 0,173 & 1,472 & 2,448 & 7,528 & 0,585 \\
\hline$Y$ & 3,455 & 0,237 & 1,781 & 14,933 & 7,676 & 1,707 \\
\hline$(L a / Y b) N$ & 9,190 & 11,488 & 10,401 & 2,907 & 10,594 & 10,598 \\
\hline$(\mathrm{La} / \mathrm{Sm}) \mathrm{N}$ & 4,538 & 5,289 & 3,317 & 0,270 & 4,315 & 1,419 \\
\hline$(\mathrm{Gd} / \mathrm{Yb}) \mathrm{N}$ & 1,867 & 2,036 & 2,722 & 9,433 & 2,037 & 5,673 \\
\hline EuN/v(Sm N* Gd N) & 0,656 & 0,725 & 0,778 & 4,884 & 0,683 & 0,960 \\
\hline $\mathrm{CeN} / \mathrm{v}\left(\operatorname{La} N^{*} \operatorname{Pr} N\right)$ & 0,890 & 0,722 & 0,979 & 0,986 & 0,899 & 1,064 \\
\hline
\end{tabular}




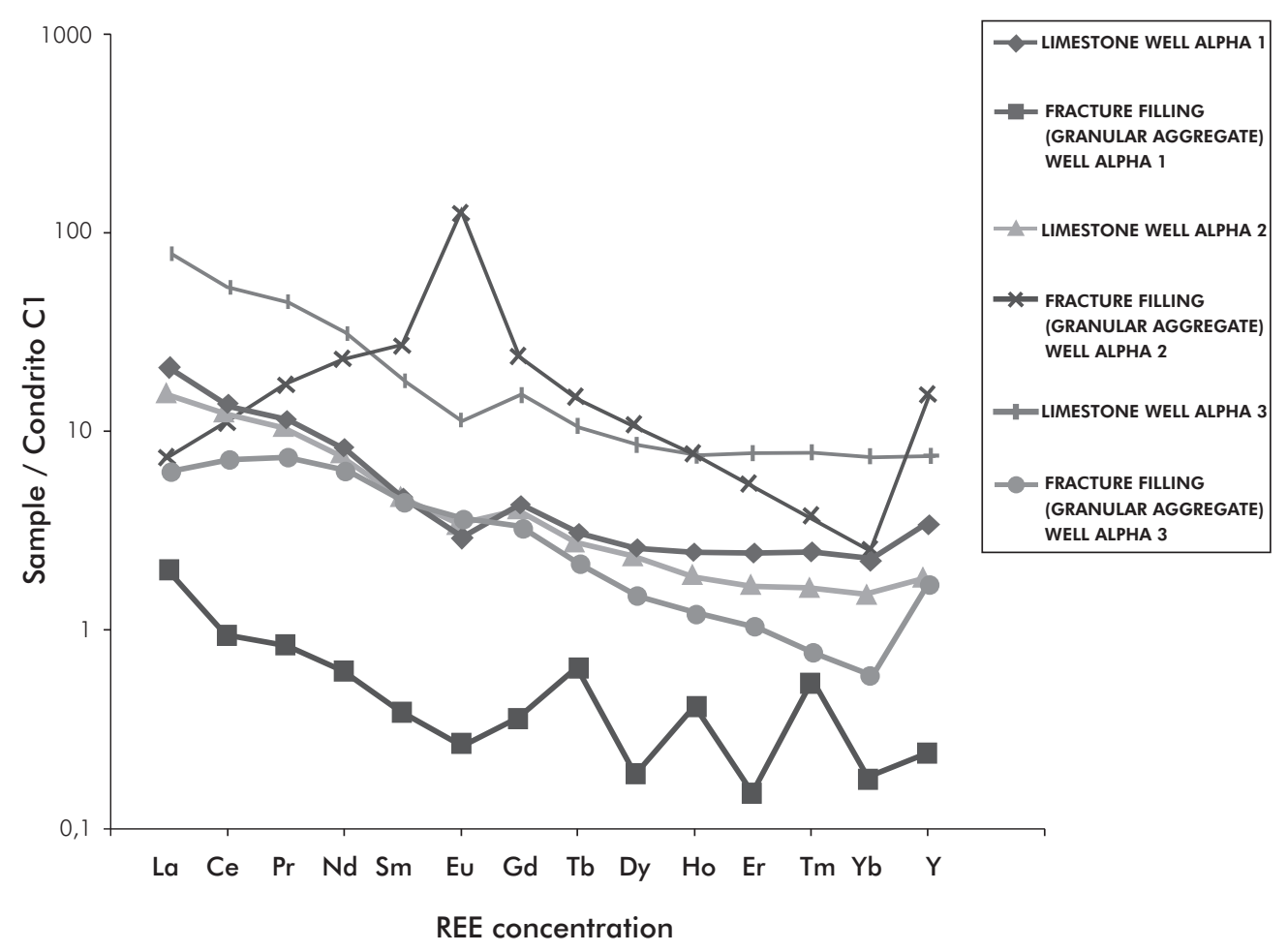

Figure 6. Standardization diagram of the REE concentrations in carbonates of granular aggregates and in samples of the box rock of the Rosablanca Formation regarding the chondrite $\mathrm{C} 1$ in wells Alpha-1 Alpha-2 and Alpha 3

\section{Fluid Inclusions}

The analysis of the fluid inclusions (FI) was done in carbonates belonging to the granular aggregates (GA), because the inclusions were well preserved in these minerals and their size was suitable for the microthermometric observations. In the granular elongated aggregates (GEA) and fibrous aggregates (FA) FI analyses could not be carried out due to their small size $(<2 \mu \mathrm{m})$.

Using the number of present phases, the composition of the liquid phase (if it is aqueous or a hydrocarbon), its origin and the grade of filling as classification criteria, the FI found in the carbonates of the granular aggregates were associated mainly in two families of fluid inclusions (FIF): FIF 1 (Figure 7a and b) is composed by primary-type FI located in isolation inside the calcite crystals, which predominantly have a regular-irregular shape, their size ranging between 8 and $40 \mu \mathrm{m}$ and are two-phase $(L H C+V$ and $L A C+V)$ and polyphase $(L A C+L H C+V)$. They are made up of a liquid aqueous phase, a liquid phase of hydrocarbons of green fluorescence under UV light whose gravitation API was estimated at around $35^{\circ} \mathrm{C}$ (Goldstein \& Reylnolds, 1994 ) and a steam phase that occupies $15 \%-20 \%$ of the volume of the fluid inclusion. These inclusions are present only in well Alpha-1.

FIF 2 (Figures 7c and d) is made up of secondary type FI in wells Alpha-1, Alpha-2 and Alpha-3 associated in transgranular guidelines, with a size that ranges between 5 - $50 \mu \mathrm{m}$ and with predominantly irregular and elongated shapes. They are single-phase (LAC) and twophase $(L A C+V)$ or $(L H C+V)$, are composed by a liquid aqueous phase or liquid phase or hydrocarbons of blue fluorescence under light UV with gravity API estimated among $40^{\circ} \mathrm{C}-45^{\circ} \mathrm{C}$ (Goldstein \& Reylnolds, 1994) and a steam phase that occupies a volume covering $5 \%$ to $10 \%$ of the FI. A summary of the microthermometric measurements appears in Table 3. 

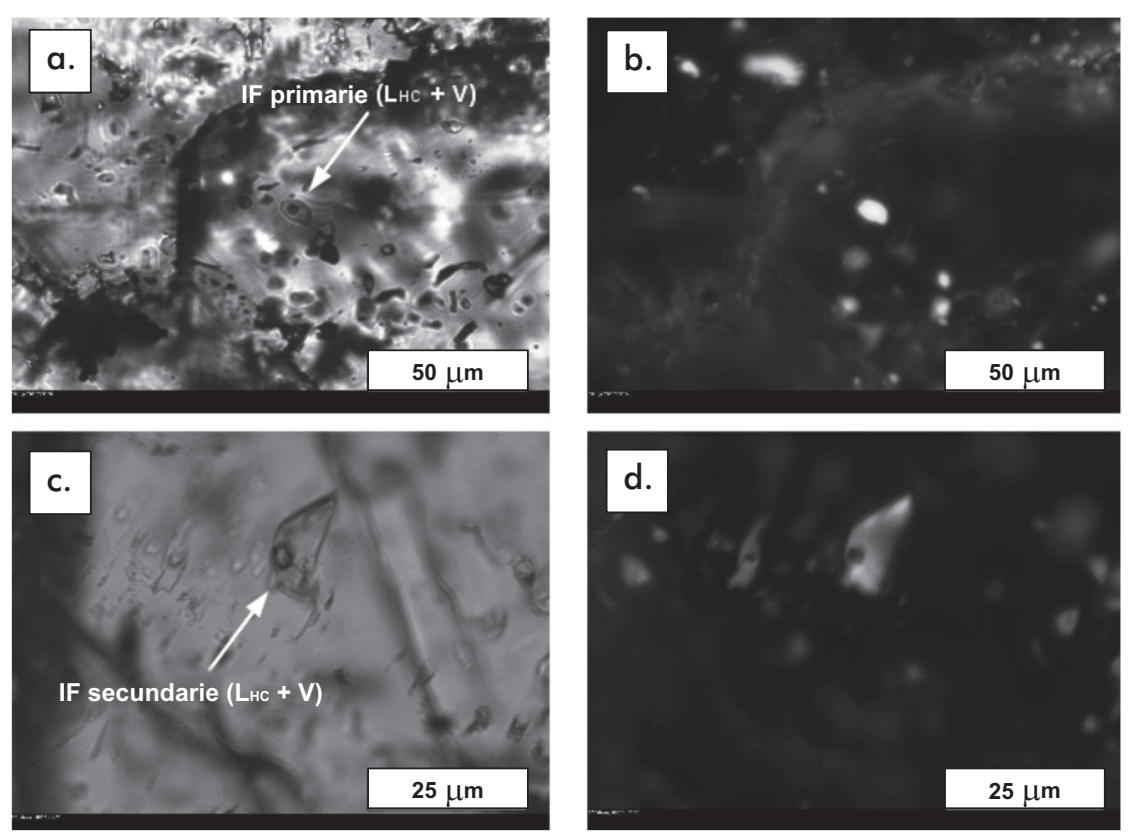

Figure 7. Microphotographs under visible and ultraviolet light. In a and b, FI (LHC+V) is of primary type and belongs to FIFI.In $c$ and $d, F I(L H C+V)$ is of secondary type and belongs to FIF

Table 3. Summary of the microthermometric measurements made in fluid aqueous inclusions (AC) and primary and secondary type hydrocarbons (HC) in the fracture-filling materials of wells Alpha-1, Alpha-2 and Alpha-3

\begin{tabular}{|c|c|c|c|c|c|c|c|c|c|c|c|c|c|c|c|c|}
\hline \multirow{2}{*}{ Well } & \multirow{2}{*}{ Depth } & \multirow{2}{*}{ Material } & \multirow{2}{*}{ Mineral } & \multirow{2}{*}{ No. IF } & \multirow{2}{*}{ Type } & \multirow{2}{*}{$\begin{array}{c}\text { Genetic } \\
\text { Clasification }\end{array}$} & \multirow{2}{*}{ FIF } & \multicolumn{3}{|c|}{$\mathrm{Th}\left({ }^{\circ} \mathrm{C}\right)$} & \multicolumn{3}{|c|}{$\operatorname{Tffh}\left({ }^{\circ} \mathrm{C}\right)$} & \multicolumn{3}{|c|}{ salinity (\%wt $\mathrm{NaCl}$ ) } \\
\hline & & & & & & & & Min & Prom & Max & Min & Prom & Max & Min & Prom & $\operatorname{Max}$ \\
\hline \multirow{7}{*}{ ALPHA 1} & \multirow{3}{*}{$6003^{\prime} 8$} & \multirow{2}{*}{ Vein } & \multirow{3}{*}{ Calcite } & 6 & $\mathrm{HC}$ & Primaries & 1 & 64,5 & 72,4 & 78,9 & & & & & & \\
\hline & & & & 1 & $\mathrm{HC}$ & Secondary & 2 & & 60 & & & & & & & \\
\hline & & & & 1 & $A C$ & Secondary & 2 & & 81 & & & $-2,2$ & & & 3,7 & \\
\hline & \multirow{4}{*}{$6021 ' 3$} & \multirow{4}{*}{ Vein } & \multirow{4}{*}{ Calcite } & 10 & $\mathrm{HC}$ & Primaries & 2 & 71,8 & 79,4 & 87,5 & & & & & & \\
\hline & & & & 3 & $A C$ & Primaries & 2 & 127,3 & 144,6 & 158,6 & $-1,7$ & $-1,5$ & $-1,1$ & $-1,9$ & 2,6 & 2,9 \\
\hline & & & & 11 & $\mathrm{HC}$ & Secondary & 2 & 65,8 & 75,4 & 87,3 & & & & & & \\
\hline & & & & 3 & $A C$ & Secondary & 2 & 73,5 & 78,6 & 87,8 & $-6,9$ & -3 & $-0,9$ & $-1,6$ & 4,6 & 10,4 \\
\hline \multirow{3}{*}{ ALPHA 2} & \multirow{2}{*}{12333} & \multirow{2}{*}{ Vein } & \multirow{2}{*}{ Calcite } & 12 & $\mathrm{HC}$ & Secondary & 2 & 27,9 & 66,8 & 96,9 & & & & & & \\
\hline & & & & 5 & $A C$ & Secondary & 2 & 114,7 & 134,6 & 163,9 & $-10,9$ & $-6,7$ & $-1,6$ & $-2,74$ & 9,5 & 14,89 \\
\hline & $12349 ' 5$ & Vein & Calcite & 4 & $A C$ & Secondary & 2 & 73,2 & 101,1 & 127,6 & $-11,6$ & $-7,6$ & -3 & 5 & 10,9 & 15,6 \\
\hline \multirow{6}{*}{ ALPHA 3} & \multirow{2}{*}{11453} & \multirow{2}{*}{ Vein } & \multirow{2}{*}{ Calcite } & 6 & $\mathrm{HC}$ & Secondary & 2 & 59,8 & 76,5 & 95,7 & & & & & & \\
\hline & & & & 4 & $A C$ & Secondary & 2 & 53,8 & 84,6 & 115,4 & $-13,5$ & $-10,5$ & $-8,9$ & 12,7 & 14,4 & 17,4 \\
\hline & \multirow{2}{*}{$11453^{\prime} 3$} & \multirow{2}{*}{ Vein } & \multirow{2}{*}{ Calcite } & 4 & $\mathrm{HC}$ & Secondary & 2 & 68,5 & 83 & 94,1 & & & & & & \\
\hline & & & & 2 & $A C$ & Secondary & 2 & 116,6 & 134,4 & 152,2 & $-8,5$ & 7,3 & -6 & 9,2 & 10,8 & 12,3 \\
\hline & \multirow{2}{*}{$116651 ' 5$} & \multirow{2}{*}{ Vein } & \multirow{2}{*}{ Calcite } & 2 & $\mathrm{HC}$ & Secondary & 2 & 73,4 & 74,6 & 76,1 & & & & & & \\
\hline & & & & 1 & $A C$ & Secondary & 2 & & 87 & & & 3,2 & & & 5,3 & \\
\hline
\end{tabular}


As can be observed in Table 3, the FI of hydrocarbons belonging to FIF 1 homogenized to liquid state $(\mathrm{LHC}+\mathrm{V}$ $\rightarrow L H C)$ at temperatures between $64,5^{\circ} \mathrm{C}$ and $87,5^{\circ} \mathrm{C}$. The aqueous FI of the same family presented eutectic temperatures between $-51,7^{\circ} \mathrm{C}$ and $-50,8^{\circ} \mathrm{C}$ during the cooling process. This indicates compositions of the type $\mathrm{H}_{2} \mathrm{O}-\mathrm{NaCl}-\mathrm{CaCl}$ and final ice melting temperatures between $-13,5^{\circ} \mathrm{C}$ and $-0,9^{\circ} \mathrm{C}$. During the heating process, homogenization to liquid state was present $(L A C+V \rightarrow$ $L A C$ ) between 127,3 and $158,6^{\circ} \mathrm{C}$.

The FI of hydrocarbons of FIF 2 homogenized to liquid state during the heating ( $L H C+V \rightarrow L H C$ ) between $31,8^{\circ} \mathrm{C}$ and $96,9^{\circ} \mathrm{C}$. The aqueous $\mathrm{FI}$ belonging to this family exhibited eutectic temperatures between $-55,1^{\circ} \mathrm{C}$ and $-50,1^{\circ} \mathrm{C}$ during the cooling process, indicating, as in the case of FIF 1, a chemical system $\mathrm{H}_{2} \mathrm{O}-\mathrm{NaCl}-\mathrm{CaCl}_{2}$, and a final ice melting temperature between $-3,5^{\circ} \mathrm{C}$ y $-0,9^{\circ} \mathrm{C}$. During the heating process, as in the case of FIF 1, homogenization to liquid state $(L A C+V \rightarrow L A C)$ took place at temperatures between $53,8^{\circ} \mathrm{C}$ and $163,9^{\circ} \mathrm{C}$. The histograms of homogenization temperatures of the FI belonging to both FIF's are illustrated in Figure 8.

\section{RESULTS ANALYSIS}

\section{Petrography}

The results obtained through the petrographic and SEM analyses carried out in the fracture-filling materials indicate that during deformational history of the Rosablanca formation, there have been at least three events of opening and filling of fractures: 1) Formation of granular aggregates (GA); 2) Formation of granular aggregates of elongated crystals (GEA); and 3) Formation of fibrous aggregates (FA). In wells Alpha-1 and Alpha 2 the presence of inclusions of enclosing rock in the crystals of the GA's indicates that they nucleated and grew in the first event from of a fluid that exerted hydrostatic pressure higher than the lithostatic pressure. This implies the formation and opening of the fracture through hydraulic fracturing mechanisms (Jébrak, 1997). During the second and third event, the GEA's and the FA's were formed, as they require the presence of previously formed fractures (Elburg, Bons, Foden \& Passhier, 2002; Bons \& Montenari, 2005) in which the crystals were developed in a preferential direction.
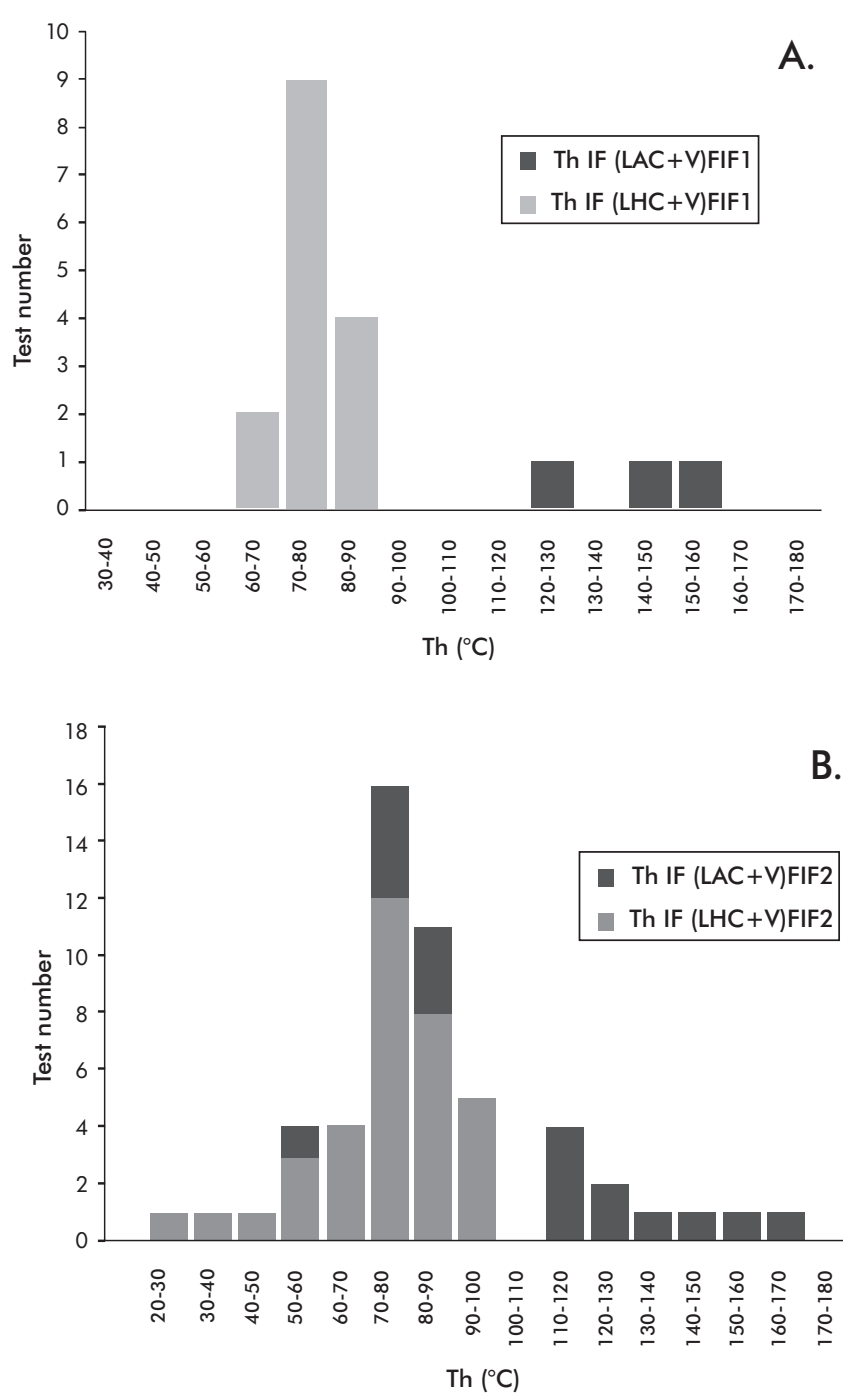

Figure 8. Histograms of homogenization temperatures. In histogram $A$, $\mathrm{Fl}$ is of primary aqueous type $(L A C+V)$ and of hydrocarbons $(L H C+V)$ belonging to FIF 1. In histogram $B, F I$ is of secondary aqueous type (LAC $+V$ ) and of hydrocarbons ( $L H C+V$ ) belonging to FIF 2

Taking into account the ideas proposed by Mišik (1971) and Dunne and Hancock (1994), the GA were formed in environments of fast fracture openings in which the opening speed was higher than that of crystal growth, and the GEA and FA were the products of a slow opening and/or very slow production of filling material. Likewise, on the basis of experimental dates obtained by Wilson (1994), it is possible to propose that the GA must have nucleated in an environment of void or negligible deformation, i.e. they must have been formed through a static growth or a free-face type growth, while the GEA and the FA must have nucleated in environments with presence of efforts, which generates a contact type growth. 
Finally, according to Cox's proposal (2005), the development of FA is associated with extensional fractures, while the development of GEA and FA is associated with hybrid extension-shear fractures.

On the basis of the observations and considerations previously mentioned, it is possible to suggest that in wells Alpha-1and Alpha-2 the GA's must have been formed in an environment of widespread extension of the basin (possibly related to its subsidence stage), while GEA and FA must have been formed in a compressional environment, possibly associated with their tectonic inversion. In well Alpha-3, considering that the GEA's cut the GA's and FA's, it is possible to suggest the existence of a late extensive event (after the deformation event associated with the generation of GEA and FA), which must have generated better conditions for fluid flow in that sector (via fractures) in a recent stage of the basin's evolution.

\section{Geochemistry of rare earth elements (REE)}

The REE data obtained from the granular aggregates that fill fractures allow us to suggest the following:

a) The REE patterns of all the enclosing rock samples belonging to the Rosablanca Formation corroborate the marine character of this unit, as indicated by the negative anomalies of Eu and $\mathrm{Ce}$. This aspect shows that the REE in this formation retain the marine character of this material.

b) The REE that were present in granular aggregates that fill fractures in well Alpha-1 were entirely removed from the limestone of the Rosablanca Formation, as inferred from the great similarity between these two compositions, the fractioning values and the values of anomalies of europium and cerium.

c) The positive Eu anomalies in well Alpha-2 and those of cerium in well Alpha-3 seem to imply a greater extraction of europium from the enclosing rock or its additional incorporation from outside.

d) The absence of negative anomaly in Eu in the granular aggregates that fill fractures in well Alpha-2 may be linked to the oxidizing environment in which the formation of these components must have occurred.
In this sense, we cannot rule out the inclusion of this element from another additional source different from the enclosing rock.

Supported on the above data, it is possible to suggest that the filling of the analyzed fractures must have developed in closed-system type environments for exploratory well Alpha-1 (intraformational flow of fluids) and in open-system type environments for exploratory wells Alpha 2 and Alpha-3 (transformational flow of fluids).

\section{Fluid Inclusions}

The data obtained from the petrographic and microthermometric analyses of FI done in granular aggregates, suggest that in the Rosablanca formation there have been at least two hydrocarbon load events throughout its geologic history. The first hydrocarbon load event, whose evidence is preserved only in well Alpha-1, occurred simultaneously with the filling of granular aggregates in this well. According to data from REE, these fluids came from the Rosablanca formation (intraformational), suggesting that this formation reached thermal maturity conditions that facilitated the generation of light type hydrocarbons (API gravity $>31,1^{\circ}$ ), which migrated through the fractures, together with aqueous-saline fluids composed of $\mathrm{H}_{2} \mathrm{O}-\mathrm{NaCl}-\mathrm{CaCl}_{2}$ with salinity values estimated between 1,9 and 3,7\% wt $\mathrm{NaCl}$ at minimum temperatures between $60-90^{\circ} \mathrm{C}$.

The second hydrocarbon load event is suggested by the presence of secondary-type fluid inclusions in wells Alpha-1, Alpha-2 and Alpha-3, indicating that it took place after the opening and filling events of fractures in the three wells. During this event there was a migration of light-type hydrocarbons associated with aqueous-saline fluids, mainly composed of $\mathrm{H}_{2} \mathrm{O}-\mathrm{NaCl}-\mathrm{CaCl}_{2}$ with a salinity level between $1,6 \%-17,4 \%$ wt $\mathrm{NaCl}$. This brinehydrocarbon mixture migrated through fracture system at temperatures estimated between $70-120^{\circ} \mathrm{C}$ according to the higher frequencies observed in the histograms and the fact that when there are simultaneous aqueous and hydrocarbon FI, the homogenization temperature of the aqueous FI represents the trapping temperature of both types of FI (Nedkvitne, Karlsen, Bjǿrlykke \& Larter, 1993). The temperature vs. salinity diagram shown in Figure 9 suggests, according to Velasco, (2004) mixing processes between hydrocarbons, low salinity meteoric type water and connate water of higher salinity. The highest recorded temperatures can also represent post- 
trapping processes experienced by the fluid inclusions after their entrapment such as Necking Down or thermal rebalancing (Goldstein \& Reynolds, 1994; Goldstein, 2001). They were possibly originated by progressive burial of the Rosablanca Formation, which meant that some FI could not keep the initial conditions of entrapment.

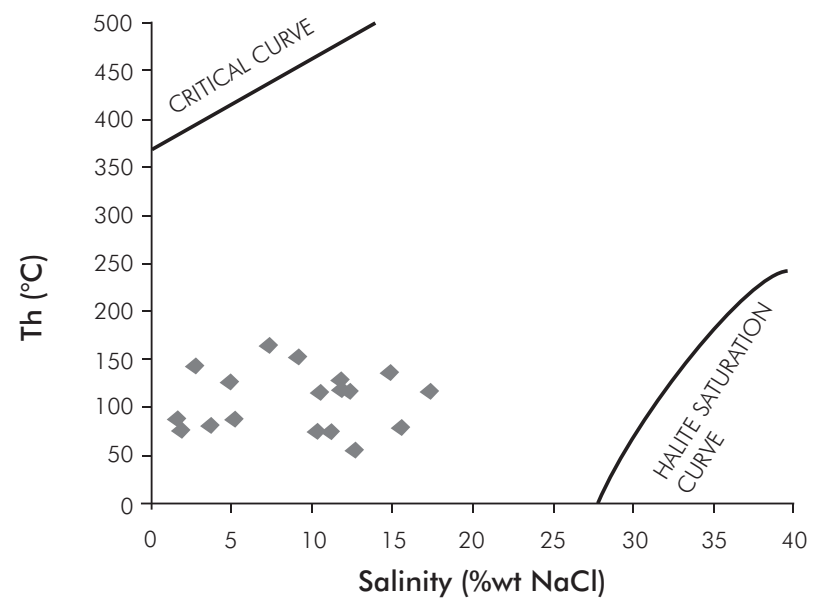

Figure 9. Diagram: Homogenization Temperature (Th) vs Salinity (\%wt $\mathrm{NaCl}$ ) for aqueous fluid inclusion of FIF 2

\section{CONCLUSIONS}

The petrographic data indicate three types of filling textures in the Rosablanca Formation:
a. Granular aggregates of calcite (GA).
b. Elongated granular aggregates of calcite (EGA).
c. Fibrous aggregates of calcite and dolomite (FA).

The formation of the GA's is associated with extension environments, while the GEA and FA must have been formed in a compressive environment, possibly associated to tectonic inversion. Considering that in exploratory well Alpha-3, the GA cut the GEA and FA, it is suggested that in that sector there must have been a late extensive tectonic event.

The geochemical REE analyses carried out in the dominant vein fillings (GA) in well Alpha-1, indicate that these fillers must have been formed in a closed system (intraformational fluid flow), while in wells Alpha-2 and Alpha-3, they must have been formed in a typical environment of open system (fluid transformational flow).

The data of fluid inclusions suggest that in the Rosablanca Formation at least two hydrocarbon load events occurred: In the first event intraformational hydrocarbons migrated, which suggests that the Rosablanca Formation might have reached thermal maturity conditions that allowed it to generate and expel light-type hydrocarbons, at minimum temperatures between $60^{\circ} \mathrm{C}-90^{\circ} \mathrm{C}$. The second event took place after the formation of the fracture fillings and lighttype hydrocarbon migrated at temperatures between $70^{\circ} \mathrm{C}-120^{\circ} \mathrm{C}$. During the second hydrocarbon load event there were mixture processes between hydrocarbons, meteoric type low-salinity waters and formation waters of higher salinity. Some microthermometric measurements indicate homogenization temperatures between $130^{\circ} \mathrm{C}-170^{\circ} \mathrm{C}$; however, due to their low percentage and suspicions of mixture or rebalancing, they are not considered in this study.

\section{ACKNOWLEDGEMENTS}

The authors are grateful to the School of Geology of the Universidad Industrial de Santander (UIS) and Ecopetrol S.A., -Instituto Colombiano del Petróleo (ICP)- particularly to the geologist Andrés Mora, director of the Cuencas Subandinas project, for his support with financial resources and for supplying the laboratory equipment necessary for the execution of the present investigation, which was developed within the framework of the Technological Cooperation Agreement No. 002 of 2006. Likewise, the authors are grateful to the reviewers of this article for the suggested improvements.

\section{REFERENCES}

Alfonso, C. A. (1985). Los episodios evaporíticos de la Formación Rosablanca. En: F. Etayo Serna y F Laverde eds. Contribuciones del proyecto cretácico. Publicaciones 
Geológicas Especiales del Ingeominas. Bogotá, Colombia, (16), 258.

Barrero, D., Pardo, A., Vargas, C. A. \& Martínez, J. F. (2007). Colombian Sedimentary Basins: nomenclature, Boundaries and Petroleum Geology, a New Proposal. Agencia Nacional de Hidrocarburos, Bogotá, Colombia. 91.

Bons, P. D., \& Montenari, M. (2005). The formation of antitaxial calcite veins with well-developed fibres, Oppaminda Creek, South Australia. J. Struc. Geol. 27: 231 - 248.

Cooper, M. A., Addison, F. T., Álvarez, R., Coral, M., Graham, R. H., Hayward, A. B., Howe, S., Martínez, J., Naar, J., Peñas, R., Pullham, A. J. \& Taborda, A. (1995). Basin development and Tectonic History of the Llanos Basin, Eastern Cordillera and Middle Magdalena Valley, Colombia. AAPG Bulletin, 79 (10), 1421-1443.

Cox, S.F. (2005). Coupling Between Deformation, Fluid Pressures, and Fluid Flow in Ore-Producing Hydrothermal Systems at Depth in the Crust. Economic Geology 100th Anniversary. $39-75$.

Dunne, W. M. \& Hancock, P. L. (1994). Palaeostress analysis of small-scale brittle structures. In: Hancock, P. (Ed.), Continental deformation. Pergamon Press, New York: U.S.A. 101-120.

Elburg, M. A., Bons, P. D., Foden, J. \& Passhier, C. W. (2002). The origin of fibrous veins: constraints from geochemistry. J. Geol. Soc., Special Publications, 200: 103 - 118.

Fabre, A. (1983). La subsidencia de la Cuenca del Cocuy (Cordillera Oriental de Colombia) durante el Cretáceo y el Terciario inferior. Segunda parte: Esquema de evolución tectónica. J. Geol. Noran. 8: 21 - 27.

Fisher, D. M. \& Brantley, S. K. (1992). Models of quartz overgrowth and vein formation: Deformation and episodic fluid flow in an ancient subduction zone. J. Geoph. Resear. 97 (B13), 2043 - 2061.

Goldstein, R. H. \& Reynolds, J. T. (1994). Systematics of Fluid Inclusions in diagenetic minerals. SEPM short course, 31, 199.

Goldstein, R. H. (2001). Fluid inclusions in sedimentary and diagenetic systems. Lithos, 55(1-4), 159-193.

Gómez, E., Jordan, T. E., Allmendinger, R. W., Hegarty, K. \& Kelley, S. (2005). Syntectonic Cenozoic sedimentation in the northern Middle Magdalena Valley Basin of Colombia and implications for exhumation of the Northern Andes. GSA Bulletin, 117 (5/6), 547-569.

Hood, S. D., Campbell, S. N. \& Kamp, P. J. J. (2003). Modification of fracture porosity by multiphase vein mineralization in an Oligocene nontropical carbonate reservoir, Taranaki Basin, New Zealand. AAPG Bulletin, 87 (10), $1575-1597$.

Jébrak, M. (1997). Hydrothermal breccias in vein-type ore deposits: A review of mechanism, morphology and size distribution. J. Ore Geol. Reviews, 12 (3), 111 - 134.

Julivert, I. Z. (1963). Estudio petrográfico de las calizas de la Formación Rosablanca de la región de la Mesa de Los Santos. Boletín de Geología, 15, 5 -34.

Kontak, D. J., Kyser, K., Gize, A. \& Marshall, D. (2006). Structurally controlled vein barite mineralization in the Maritimes Basin of Eastern Canada: Geologic Setting, Stable Isotopes and Fluid Inclusions. Economic Geology, 101, 407 - 430 .

León, J. O. (2002). Análisis Estratigráfico de la Formación Rosablanca en la cuenca del Valle Medio del Magdalena. Tesis de grado. Universidad Industrial de Santander, Bucaramanga, Colombia, 113pp.

Mantilla, F. L., Tassinari, C. C. \& Mancini, L. H. (2006). Estudio de Isótopos de C, O, Sr y de elementos de tierras raras (REE) en rocas sedimentarías Cretáceas de la Cordillera Oriental (Santander, Colombia): Implicaciones Paleohidrológicas. Boletín de Geología, 28 (1), 61 - 80.

Misik, (1971). Observations Concerning Calcite Veinlets in Carbonate Rocks. J. Sedi. Reser. 41: 450 - 460.

Morales, L. G., Podesta, D. J., Hatfield, W. C., Tanner, H., Jones, S. H., Barker, M. H., O’Donoghue, D. J., Mohler, C. E., Dubois, E. P., Jacobs, C. \& Goss, C. R. (1958). General Geology and oil occurrences of the Middle Magdalena Valley, Colombia. Habitat of Oil Symposium. Tulsa. J. Amer. Assoc. Petro. Geol, 41: 695.

Naranjo, J. F., Duque, N. \& Moreno, N. (2009). Definición de eventos diagenéticos y carga de hidrocarburos mediante estudios de petrología en la Formación Rosablanca, Cuenca del Valle Medio del Magdalena. X Simposio Bolivariano Exploración petrolera en Cuencas Subandinas. Cartagena, Colombia. 
Nedkvitne, T., Karlsen, D. A., Bjǿrlykke, K. \& Larter, S. (1993). Relationship between reservoir diagenetic evolution and petroleum emplacement in the Ula Field, North Sea. J. Mar. Pet. Geol. 10, 255 - 270.

Rollinson, H. (1996). Using geochemical data: evaluation, presentation, interpretation. Michigan: Longman Scientific \& Technical, 352.

Rolon, L. \& Numpaque, L. (1997). Análisis estratigráfico secuencial del Cretáceo Inferior en el Valle Medio del Magdalena, sector piedemonte occidental de la Cordillera oriental. Informe técnico, Ecopetrol S. A., Bogotá, Colombia. 120.

Sarmiento, L. F. (2001). Mesozoic Rifting and Cenozoic Basin Inversion History of the Eastern Cordillera, Colombian Andes. Inference from tectonic models, Disertación Doctoral, Universidad de Amsterdam, Amsterdam 295pp.

Suchy, V., Heijlen, W., Sykorova, I., Muchez, Ph., Dobes, Hladikova, J., Jackova, I., Safanda, J. \& Zeman, A. (2000). Geochemical study of calcite veins in the Silurian and devonian of the Barrandian Basina (Czech Republic): evidence for widespread post-Variscan fluid flow in the central part of the Bohemian Massif. Prague, Czech Republic. J. Sed. Geol. 131: 201 - 209.

Taylor, S. R., \& McLennan, S. M. (1985). The continental crust: its composition and evolution. Oxford: Blackwell Scientific.

Velasco, F. (2004). Introducción al Estudio de las Inclusiones Fluidas. XXIII Curso Latinoamericano de Metalogenia, Mendoza, España. 98.

Villamil, T. (1999). Campanian-Miocene tectonostratigraphy, depocenter evolution and basin development of Colombia and western Venezuela. Palaeogeography, Palaeoclimatology, Palaeoecology, 153 (1-4), 239 - 275.

Wilson, C. J. L. (1994). Crystal growth during a single-stage opening event and its implications for syntectonic veins. J. Struc.Geol. 16 (9), 1283-1296. 